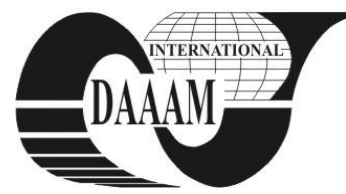

Annals of DAAAM for 2011 \& Proceedings of the 22nd International DAAAM Symposium, Volume 22, No. 1, ISSN 1726-9679 ISBN 978-3-901509-83-4, Editor B. Katalinic, Published by DAAAM International, Vienna, Austria, EU, 2011 Make Harmony between Technology and Nature, and Your Mind will Fly Free as a Bird Annals \& Proceedings of DAAAM International 2011

\title{
A CONTROL SYSTEM FOR MOBILE FORESTRY CABLEWAY WITH HYDROSTATIC DRIVES PART 1
}

\author{
PROCHAZKA, P[etr]; KLIMA, B[ohumil] \& HUTAK, P[etr]
}

\begin{abstract}
A mobile forestry logging cableways are used in hardly accessible forest terrains. Modern cableways must meet a number of requirements. Some of them are safety, reliability, handling ergonomics and comfort, operating performance operating costs etc. Wood logging principles and technology are quite complex and are described in many papers focused on this technical area (Freedman et al., 1995), (Goldenberg et al., 1995), (Junmei et al., 2007) and (Papadopoulos \& Sarkar, 1997). This paper is focused on mechanic system. Driving and control system is described in the other paper "A Control System for Mobile Forestry Cableway with Hydrostatic Drives part 2" (This paper is presented at this conference too).

Key words: forestry cableway, winding drums control, hydrostatic drives
\end{abstract}

\section{INTRODUCTION}

Forestry cableways are steel rope-way systems where fully or partially suspended loads are moved by means of moving cables. There exist many configurations from tractor-mounted winches (used to extract timber by skidding on ground too difficult for horse extraction) up to modern sophisticated systems constructed as a special trailor or on a truck which are temporarily built in forest to extract timbers from a certain space in forest. One of them is Larix H3 650P - trailor version or Larix H3 650A - truck version. In general forestry cableway is a complex mechatronic system requiring sophisticated and robust control.

\section{CABLEWAY MECHANIC SYSTEM}

Main parts of such cableway are mobile chassis (trailor or truck), hydraulic foldaway tower with pulleys, a set of winding drums with cables and their driving system. A carriage cooperates with the cableway. The number of winch drums depends on required configuration of logging and on carriage system requirements. Larix $\mathrm{H} 3650 \mathrm{P}$ has three operating drums (skyline, mainline, haul-back line), four anchor drums and one drum for lightweight textile straw line.

The carriage has two tasks during cableway operation. At first to roll into stock-yard timber loaded or roll back unloaded into forest for next timbers at the strung skyline. The second task is to pull up the timbers using mainline slack and pull out the slack for hanging the timber or when the load is put down. The carriage must contain some additional mechanical system for the slack operation. There are several slack pulling systems: driven by auxiliary (slack-pulling) line, using auxiliary combustion machine in carriage or modern and the most-used one using working ropes. Larix H3 650 uses carriage Sherpa U3 from Franz Mayr-Melnhof-Saurau, Austria.

The carriage Sherpa U3 contains rollers for movement on skyline and clamps which can lock the carriage on the skyline. Next part of the carriage system is a drum for haul-back line which is joined (rotates together) with a pulling tackle for main line and next clamps for locking mainline slack. The carriage works in two states during standard operation. When carriage moves on skyline, the skyline clamps are unlocked and mainline clamps are locked. The load is hanged in constant distance under carriage. The second state is when timber is pulled up or down.

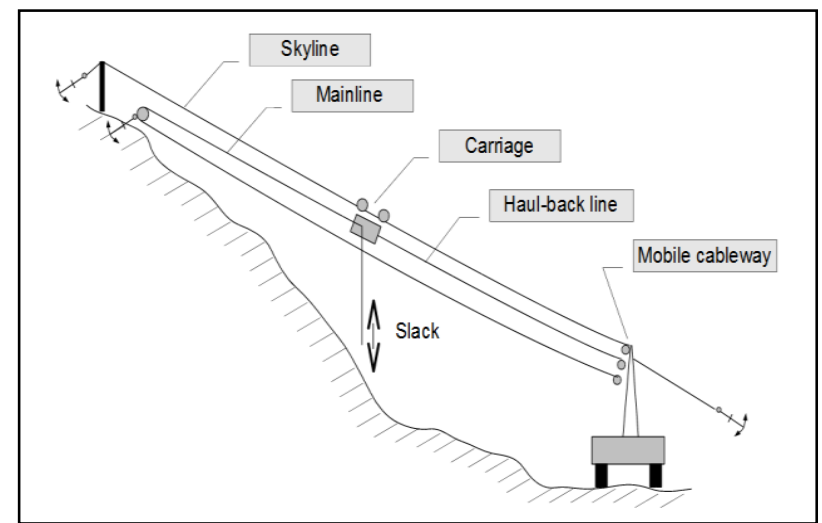

Fig. 1. Logging configurations of forestry cableway

Figure represents downhill logging

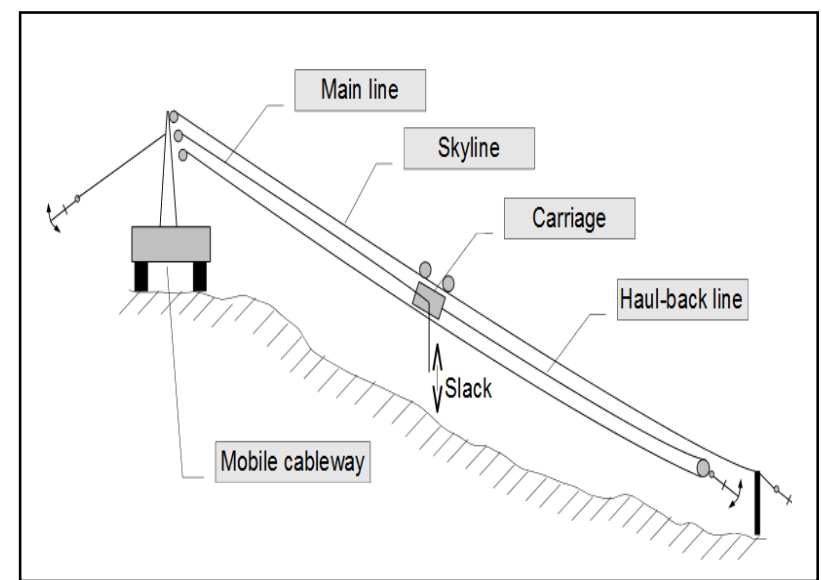

Fig. 2. Logging configurations of forestry cableway

Figure represents uphill logging

In this state skyline clamps are locked and mainline clamps are unlocked. The carriage is fixed on skyline and cableway can pull haul-back line to eject mainline slack or pull mainline to attract load toward carriage and simultaneously wind up haul back line onto winch in carriage. Energy for ropes operation is supplied from cableway winches. Both clamps are driven by hydraulic cylinders. Energy for its operation is stored in a pressure reservoir by a pump driven from a skyline roller. The carriage receives clamps switching commands from cableway wireless transmitter. Carriage electric system is supplied from an accumulator.

The cableway supports two logging configurations shown in fig. 1 downhill and fig. 2 uphill logging. In both cases 
skyline is strung between cableway tower and any tree at the end of track. Anchoring issues of cableway system will not be described more. In case of uphill operation the mainline is introduced directly from tower pulley into the carriage and haul-back line leads into carriage over a pulley at the end of track. In downhill configuration breaking of the load using mainline is supposed (mainline is stronger than haul-back line) and the mainline leads over the end track pulley. Key parameters of the cableway are shown in Tab. 1.

\begin{tabular}{|l|c|}
\hline \multicolumn{1}{|c|}{ Parameter } & Value \\
\hline Engine Iveco & $93 \mathrm{~kW}$ \\
\hline Max. track length & $700 \mathrm{~m}$ \\
\hline Mainline max. force & $32 \mathrm{kN}$ \\
\hline Cableway mass (including full length ropes) & $11 \mathrm{t}$ \\
\hline Carriage speed unloaded/loaded & $8 / 5 \mathrm{~m} / \mathrm{s}$ \\
\hline
\end{tabular}

Tab. 1. Forestry Cableway LARIX H3 650 Parameters

\section{WINCHES DRIVING SYSTEM, SENSORS AND CONTROL INPUTS}

A driving system consists of three independent hydraulic loops - each of them is for one winch. Scheme of the system is shown in fig. 3. Pumps of these hydraulic circuits are driven by common combustion engine. Oil volume per one round is proportional to current signal $(-\max$. volume/round $\div+\max$. volume/round corresponds $-50 \div+50 \mathrm{~mA}$ ). Hydrostatic motors are supplied by corresponding pumps. They are able to produce force and also high speed operation requirements of all winches. The system of hydrostatic pump and motor can be understood as gear unit with continuously variable speed defined by number of rounds per volume unit. Additionally it is possible to switch its rounds/volume number in ratio 1:3 by binary control signal connected to motor coil. The switching of motor ratio can be understood as a "two step" field-weakening of electric motors. All pumps and motors are products of SauerDanfoss company (*** 2009).

It is clear that the pressure sensor must be placed in branch of hydraulic circuit in which operating pressure is present when rope is wound on. Pressure sensor output is a standard two-wire $4 \div 20 \mathrm{~mA}$ interface.

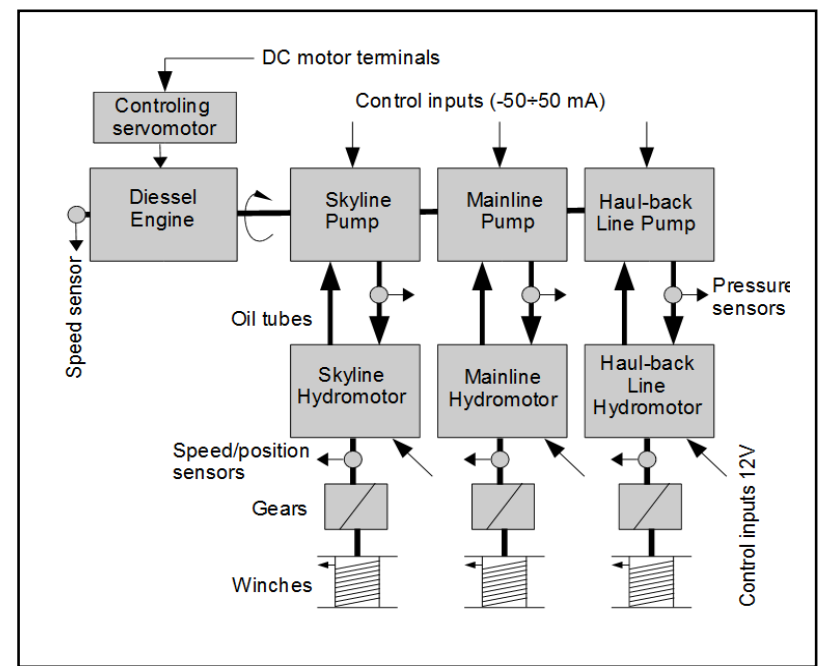

Fig. 3. Driving system of cableway winches and its sensors and control inputs

A constant speed ratio planetary gearbox and winch drum is behind each motor. A pulse position/speed sensor is placed on the shaft of each motor. The speed sensor has four-wire interface with TTL voltage levels - two wires for supplying $5 \mathrm{~V}$, one for pulses and one for rotation direction. The placement of the sensor in front of gearbox allows rope length resolution (winch circumference resolution) in units of millimeters. The diameter variation of mainline and haul-back line by number of turns is insignificant.

Combustion engine is the last important part of driving system. Linear actuator with DC motor $12 \mathrm{~V} / 2 \mathrm{~A}$ is used for fuel pump lever control. The engine speed sensing is based on frequency measurement of the AC voltage alternator.

\section{CONCLUSION}

In conclusion it is suitable to summarize some advantages of hydrostatic drives and to make a comparison with an electric equivalent. The main advantages of hydrostatic drives are excellent mechanical durability and vibration resistivity of whole system. Very interesting are their volumes and weights. $100 \mathrm{~kW}$ pump or hydro-motor have approximately $12 \mathrm{dm}^{3} / 60$ $\mathrm{kg}$. The same power asynchronous electric machine has 220 $\mathrm{dm}^{3} / 650 \mathrm{~kg}$. In addition the electric drive needs an inverter for continuous control which is also an item with some significant volume and wieght. On the other hand the hydrostatic drives use thick tubes, they need oil reservoir and other equipment. They have higher requirement on maintenance costs too (periodic oil filtering and changing).

The next possible improvement of the cableway will be replacement of the "two step" hydro-motors by the proportional hydro-motors.

\section{ACKNOWLEDGEMENTS}

The contribution was partially supported by projects CZ.1.05/2.1.00/01.0014 "Center for Research and Utilization of Renewable Energy Sources" of the Ministry of Education, Youth and Sports of the Czech Republic and MSM 0021630516 of the Ministry of Education, Youth and Sports of the Czech Republic.

\section{REFERENCES}

Freedman P., Papadopoulos E., Poussart D., Gosselin C., Courteau J., (1995). Application of Robotic Technologies to Forestry Equipment, Electrical and Computer Engineering, Vol.2, (September 1995), (1140 - 1143), ISSN 0840-7789

Goldenberg, A.A. Wiercienski, J. Kuzan, P. Szymczyk, C. Fenton, R.G. Shaver, B. (1995). A remote manipulator for forestry operation, Robotics and Automation IEEE Transactions, Vol. 11, No. 2, (April 1995), (185 - 197), ISSN 1042-296X

Junmei Z, Wenbin L, Chao S, Deming W, Chua, P.S.K., Tan F.L. (2007). Development of a CPLD Based Wireless Remote Control System of Pruning Machine for Plantation Forest, Proceedings of Computer Supported Cooperative Work in Design, 2007. CSCWD 2007, Melbourne, Australia, ISBN 1-4244-0963-2, Weiming Shen (Ed.), pp. 1078 - 1081, Melbourne

Papadopoulos, E. Sarkar, S. (1997). The dynamics of an articulated forestry machine and its applications, Proceedings of Robotics and Automation IEEE nternational Conference, Vol.1., ISBN 0-7803-3612-7, pp. 323 - 338

*** (2009) http://www.sauer-danfoss.com - Bent Axis Variable Displacement Motors, Technical Information Dunfoss, Accesses on: 2011-09-01 